fluid has been removed. Unless there is a contraindication heparin ( 500 units/1) is added to the dialysate, while antibiotics and additional electrolytes including potassium may also be added as required.

Since the introduction of the cannula we have used it to dialyse on average one or two infants a month. No mortality or morbidity has been associated with use of this equipment, and effective dialysis was achieved in every case.

\section{Discussion}

The principles of peritoneal dialysis in children are the same as those in adults and have been described previously. ${ }^{4} \mathrm{~A}$ particular problem, however, is posed by infants who require delivery of small and accurately measured volumes of warmed dialysate via a suitably sized cannula to the peritoneum, and accurate measurement of the effluent. Automated equipment is available for older children, but its use in the newborn especially is limited because small enough volumes of dialysate cannot always be delivered and the dialysate content cannot be altered readily. Moreover, automated equipment can be used only by staff who have been specially trained, thus restricting its use to dialysis centres. In the past non-automated open dialysis systems have had to be made up using intravenous giving sets, thus increasing the risk of contamination. Finally, the suitability of the peritoneal cannula has proved a problem in infants, in whom large cannulas with a trocar (as opposed to a sharp short bevelled needle) are particularly apt to cause damage to abdominal viscera.

The new cannula and dialysis set has the following advantages compared with previously available equipment: insertion of the cannula is easier, quicker, and less traumatic; there is less risk of contaminating the dialysate since the tubing set is unbroken from dialysate supply to cannula; the dialysate mix being used may be altered easily and conveniently without interrupting dialysis; and the equipment is much easier for relatively unskilled staff to assemble.

\section{References}

1 Chantler C. Renal failure in childhood. In: Black D, Jones NF, eds. Renal disease. 4th ed. Oxford: Oxford Press, 1979:825-68.

Haycock GB. Acute renal failure in infancy and childhood. In: Andreucci VE, ed. Acute renal failure. The Hague: Martinus Nijhoff Medical Division (in press).

Chantler C. The kidney. In: Godrey DS, Baum JD, eds. Clinical paediatric physiology. Oxford: Blackwell Scientific, 1979:391-8.

4 Scharer K, Chantler C, Donckerwolcke RA. Peritoneal dialysis. In: Drukker W, Parsons F, Maher JF, eds. Replacement of renal function by dialysis. The Hague: Martinus Nijhoff Medical Division, 1978:444-61.

(Accepted 5 fanuary 1983)

\title{
Acute respiratory distress in diabetic ketoacidosis: possible contribution of low colloid osmotic pressure
}

\author{
R C F LEONARD，C ASPLIN，C V MCCORMICK，T D R HOCKADAY
}

\begin{abstract}
The "shock lung" syndrome may occur in diabetic ketoacidosis in association with disseminated intravascular coagulation; occasionally it occurs alone after treatment of the ketoacidosis. Two patients developed pulmonary opacities with clinical features of acute respiratory distress such as are seen in the shock lung syndrome; in both, however, the findings suggested a different mechanism from that occurring in the syndrome. Hypoalbuminaemia was prominent, and it is postulated that a low plasma osmotic pressure caused by high volume crystalloid infusions may have precipitated the acute respiratory complications.

Plasma osmotic pressure may be an important variable in patients given large volumes of crystalloid infusions; further studies are required to elucidate mechanisms of pulmonary oedema in such patients.
\end{abstract}

\section{Introduction}

The "shock lung" syndrome, a discrete clinicopathological entity, has been described in diabetic ketoacidosis in association

John Radcliffe Hospital, Oxford

R C F LEONARD, MD, MRCP, senior registrar

C ASPLIN, MD, MRCP, senior registrar

C V MCCORMICK, MRCP, registrar

T D R HOCKADAY, MD, FRCP, consultant

Correspondence to: Dr R C F Leonard, Department of Clinical Oncology, Western General Hospital, Edinburgh EH4 2XU with disseminated intravascular coagulation. ${ }^{1}$ Disseminated intravascular coagulation, sometimes with cerebral intravascular coagulation, is a well recognised feature of ketoacidosis. ${ }^{23}$ Occasional reports, however, have indicated that pulmonary oedema may develop without disseminated intravascular coagulation after the treatment of diabetic ketoacidosis. ${ }^{4-6}$

We report on two patients with diabetic ketoacidosis who developed radiological pulmonary opacities with clinical features of acute respiratory distress such as are seen in the shock lung syndrome but in whom the findings suggested a different mechanism from that occurring in the syndrome.

\section{Case reports}

CASE 1

A 34 year old electronics engineer presented with severe diabetic ketoacidosis. He had a three month history of weight loss, polyuria, and polydipsia and increasing confusion. He was appreciably dehydrated, but there was no evidence of infection, the lungs were clear, and a chest $x$ ray film was normal. He was acidotic and was given $100 \mathrm{mmol}(\mathrm{mEq})$ sodium bicarbonate as well as physiological saline, potassium, and soluble insulin; the volume infused over the first 12 hours was 5.51 .

There was a good initial response, but on day 3 he suddenly developed severe dyspnoea and cyanosis. Auscultation of the chest disclosed widespread coarse crepitations, but jugular venous pressure was normal. Arterial hypoxaemia was confirmed, and a chest $x$ ray film showed bilateral pulmonary oedema without cardiac enlargement, compatible with the shock lung syndrome. He was transferred to the intensive therapy unit, where a Swan Ganz catheter was inserted and pulmonary vascular pressures were found to be normal.. Blood cultures were negative and he was treated initially with oxygen by 
mask. His condition deteriorated further, however, and he required intermittent positive pressure ventilation.

Although the shock lung syndrome had been diagnosed, there was no evidence of disseminated intravascular coagulation on clinical or biochemical testing. He made a good recovery over the next few days, receiving ventilation, antibiotics, and insulin. Table I shows the changes in his blood gas tensions and biochemical variables. Later inquiry elicited a history of alcohol abuse in the recent past. He eventually made a complete recovery.

CASE 2

A 34 year old man was seen in medical outpatients with a history of polyuria, polydipsia, and weight loss of several months' duration. Diabetes mellitus was diagnosed and admission arranged for a few days ahead. Within 48 hours, however, he was admitted as an emergency with pronounced ketoacidosis and dehydration. There was no evidence of infection, the lungs were clear, and a chest $x$ ray film was normal. $\mathrm{He}$ was treated with physiological saline, potassium, and soluble insulin, receiving 51 fluid over the first 12 hours.

Twelve hours after admission he developed sudden dyspnoea and there were widespread coarse crepitations. Repeat blood gas analysis confirmed hypoxaemia. A chest $x$ ray film showed widespread pulmonary oedema without cardiac enlargement, compatible with the shock lung syndrome, and he was sent to the intensive therapy unit for intermittent positive pressure ventilation. On the second day his blood urea concentration rose sharply and cyanosis of the feet developed. The platelet count fell from $200 \times 10^{9} / 1\left(200 \times 10^{3} / \mathrm{mm}^{3}\right)$ to $110 \times 10^{9} / 1\left(110 \times 10^{3} / \mathrm{mm}^{3}\right)$, and concentrations of fibrin degradation products were raised. Acute renal failure developed, and he was ill for 10 days with peripheral gangrene and persistent lung disease before clinical, radiological, and biochemical variables improved (table II). Three weeks after admission he was able to breathe unassisted, and he made a good recovery despite requiring amputation of the left lower leg. Later inquiry elicited a history of alcohol abuse before his illness.

\section{Discussion}

These cases had some interesting features in common. In both respiratory distress occurred 12 to 48 hours after $\propto$ treatment for diabetic ketoacidosis with large volumes of $c$ crystalloid infusions. The respiratory illness was dramatically sudden in onset in both patients and was unresponsive to conventional measures other than intermittent positive pressure ventilation. In neither case was there evidence of heart failure, and in case 1 pulmonary vascular pressures were normal. Disseminated intravascular coagulation was excluded in case 1 and in case 2 was not detected until the acute respiratory illness was established. In both cases the radiologist interpreted the radiographs as showing widespread bilateral pulmonary oedema typical of the findings in the shock lung syndrome or adult respiratory distress syndrome. The plasma albumin concentration, high in both cases at presentation, fell sharply over the period before and just after the acute respiratory illness and early on appeared to parallel the fall in arterial oxygen tension.

It thus appears that the first patient, and probably the second, developed acute pulmonary oedema without disseminated intravascular coagulation and without evidence of cardiac disease or a sudden rise in venous pressure. We postulate that a fall in plasma osmotic pressure was the event leading to pulmonary oedema. The probable importance of low plasma osmotic pressure in pulmonary oedema is recognised, ${ }^{6}{ }^{7}$ but clinical studies implicating this as a mechanism are few. Stein et $a l,{ }^{8}$ however, in a study of severely ill hypovolaemic patients, showed that crystalloid infusions caused a significant fall in plasma osmotic pressure and that plasma osmotic pressure was a better predictor of the subsequent pulmonary oedema than left ventricular filling pressure. In our two cases the plasma albumin concentration fell steeply and may have produced an appreciable fall in plasma osmotic pressure. The mechanisms

TABLE I-Variables measured in case 1 throughout course of illness

\begin{tabular}{|c|c|c|c|c|c|c|c|c|c|c|c|}
\hline & \multicolumn{11}{|c|}{ Days } \\
\hline & 1 & 2 & $3^{*}$ & 4 & $5+$ & 6 & 7 & 8 & 9 & 10 & $11 \ddagger$ \\
\hline \multicolumn{12}{|c|}{ Fluid balances } \\
\hline $\begin{array}{l}\text { Total }(\mathrm{ml} / 24 \mathrm{~h}) \\
\text { Intravenous }(\mathrm{ml} / 24 \mathrm{~h}) \\
\text { Balance }(\mathrm{ml} / 24 \mathrm{~h})\end{array}$ & $\begin{array}{r}7910 \\
7910 \\
+1355\end{array}$ & $\begin{array}{r}3320 \\
3320 \\
+920\end{array}$ & $\begin{array}{r}4320 \\
4320 \\
+2600\end{array}$ & $\begin{array}{r}2950 \\
2540 \\
+175\end{array}$ & $\begin{array}{r}10420 \\
8300 \\
+6020\end{array}$ & $\begin{array}{r}4600 \\
2400 \\
+124\end{array}$ & $\begin{array}{r}6207 \\
3020 \\
-917\end{array}$ & $\begin{array}{r}3222 \\
1362 \\
-615\end{array}$ & $\begin{array}{r}2667 \\
1797 \\
-574\end{array}$ & $\begin{array}{r}11347 \\
2904 \\
+1512\end{array}$ & $\begin{array}{r}2927 \\
0 \\
-607\end{array}$ \\
\hline \multicolumn{12}{|c|}{ Blood gas analysis } \\
\hline $\begin{array}{l}\text { Arterial pH } \\
\text { Oxygen tension }{ }^{* *}(\mathrm{kPa})\end{array}$ & $\begin{array}{l}6.91 \\
16.9\end{array}$ & $\begin{array}{r}7 \cdot 2 \\
13 \cdot 6\end{array}$ & $\begin{array}{l}7 \cdot 31 \\
8 \cdot 5\end{array}$ & $\begin{array}{l}7 \cdot 32 \\
5 \cdot 1\end{array}$ & $\begin{array}{l}7 \cdot 45 \\
5 \cdot 9\end{array}$ & $\begin{array}{l}7 \cdot 4 \\
4 \cdot 99\end{array}$ & $\begin{array}{l}7 \cdot 49 \\
6 \cdot 2\end{array}$ & $\begin{array}{l}7.53 \\
6.50\end{array}$ & $\begin{array}{l}7 \cdot 46 \\
8 \cdot 2\end{array}$ & $\begin{array}{c}7 \cdot 54 \\
12 \cdot 3\end{array}$ & $\begin{array}{l}7 \cdot 45 \\
17 \cdot 3\end{array}$ \\
\hline \multicolumn{12}{|c|}{ Biochemical variables } \\
\hline $\begin{array}{l}\text { Albumin }(\mathrm{g} / \mathrm{l}) \\
\text { Glucose }(\mathrm{mmol} / \mathrm{l}) \\
\text { Urea }(\mathrm{mmol} / \mathrm{l})\end{array}$ & $\begin{array}{r}49 \cdot 0 \\
21 \cdot 1 \\
6.0\end{array}$ & $13 \cdot 5$ & $\begin{array}{r}43 \cdot 0 \\
9 \cdot 0 \\
5 \cdot 8\end{array}$ & $\begin{array}{r}32 \cdot 0 \\
5 \cdot 5\end{array}$ & $\begin{array}{l}36 \cdot 0 \\
12 \cdot 2\end{array}$ & $\begin{array}{l}7 \cdot 5 \\
6 \cdot 4\end{array}$ & & $\begin{array}{r}28 \cdot 0 \\
6 \cdot 2\end{array}$ & $\begin{array}{r}28 \cdot 0 \\
5.5\end{array}$ & $\begin{array}{r}33.0 \\
6.3\end{array}$ & 3.0 \\
\hline
\end{tabular}

*Transferred to intensive therapy unit for oxygen. †Intubated for intermittent positive pressure ventilation. $\ddagger$ Extubated and given $40 \%$ oxygen by mask. $*$ Measured when patient off ventilator.

Conversion: SI to traditional units-Oxygen tension: $1 \mathrm{kPa} \approx 7.5 \mathrm{~mm} \mathrm{Hg}$. Glucose: $1 \mathrm{mmol} / 1 \approx 18 \mathrm{mg} / 100 \mathrm{ml}$. Urea: $1 \mathrm{mmol} / 1 \approx 6 \mathrm{mg} / 100 \mathrm{ml}$.

TABLE II-Variables measured in case 2 throughout course of illness

\begin{tabular}{|c|c|c|c|c|c|c|c|c|c|c|}
\hline & \multicolumn{10}{|c|}{ Days } \\
\hline & 1 & $2 *$ & 3 & $4 \dagger$ & 5 & 6 & 7 & 8 & $9 \ddagger$ & 10 \\
\hline \multicolumn{11}{|c|}{ Fluid balances } \\
\hline $\begin{array}{l}\text { Total }(\mathrm{ml} / 24 \mathrm{~h}) \\
\text { Intravenous }(\mathrm{ml} / 24 \mathrm{~h}) \\
\text { Balance }(\mathrm{ml} / 24 \mathrm{~h})\end{array}$ & $\begin{array}{r}7775 \\
7500 \\
+4525\end{array}$ & $\begin{array}{r}3250 \\
3250 \\
+2750\end{array}$ & $\begin{array}{r}4260 \\
4260 \\
+2890\end{array}$ & & $\begin{array}{r}3725 \\
2640 \\
+1650\end{array}$ & & $\begin{array}{r}2360 \\
1580 \\
+1025\end{array}$ & $\begin{array}{r}2080 \\
1025 \\
+975\end{array}$ & $\begin{array}{r}2770 \\
1560 \\
+1010\end{array}$ & $\begin{array}{r}2550 \\
1070 \\
+625\end{array}$ \\
\hline \multicolumn{11}{|c|}{ Blood gas analysis } \\
\hline $\begin{array}{l}\text { Arterial pH } \\
\text { Oxygen tension }(\mathrm{kPa})\end{array}$ & $\begin{array}{r}7 \cdot 01 \\
13 \cdot 2\end{array}$ & $\begin{array}{l}7 \cdot 1 \\
7 \cdot 5\end{array}$ & 7.3 & $(\mathrm{ON} \mathbf{7} \mathrm{V}$ & (LATOR) & {[} & $\begin{array}{r}7 \cdot 4 \\
13 \cdot 3\end{array}$ & & & $12 \cdot 7$ \\
\hline \multicolumn{11}{|c|}{ Biochemical variables } \\
\hline $\begin{array}{l}\text { Albumin }(\mathrm{g} / \mathrm{l}) \\
\text { Glucose }(\mathrm{mmol} / \mathrm{l}) \\
\text { Urea (mmol/l) }\end{array}$ & $\begin{array}{l}48 \cdot 0 \\
27 \cdot 0 \\
19 \cdot 0\end{array}$ & $\begin{array}{l}24 \cdot 0 \\
17 \cdot 0 \\
30 \cdot 6\end{array}$ & $\begin{array}{l}23.0 \\
13.8 \\
49.8\end{array}$ & $\begin{array}{l}24 \cdot 0 \\
17 \cdot 0 \\
39 \cdot 0\end{array}$ & $\begin{array}{l}24 \cdot 0 \\
13 \cdot 0 \\
29 \cdot 2\end{array}$ & $\begin{array}{r}20 \cdot 0 \\
9 \cdot 3 \\
20 \cdot 1\end{array}$ & $\begin{array}{r}27 \cdot 0 \\
6.7 \\
32 \cdot 0\end{array}$ & $\begin{array}{l}23 \cdot 0 \\
25 \cdot 0\end{array}$ & $22 \cdot 0$ & $\begin{array}{r}23.0 \\
6.5 \\
26.0\end{array}$ \\
\hline
\end{tabular}

*Intermittent positive pressure ventilation started. $\nmid$ Peritoneal dialysis started; disseminated intravascular coagulation noted, fibrin degradation products raised. $\ddagger$ Intermittent positive pressure ventilation stopped.

Conversion: SI to traditional units-Oxygen tension: $1 \mathrm{kPa} \approx 7.5 \mathrm{~mm} \mathrm{Hg}$. Glucose: $1 \mathrm{mmol} / 1 \approx 18 \mathrm{mg} / 100 \mathrm{ml}$. Urea: $\mathrm{Lmmol} / 1 \approx 6 \mathrm{mg} / 100 \mathrm{ml}$. 
contributing to the fall in plasma albumin concentration may have included at least two factors-namely, rehydration with crystalloid solutions as the major factor and reduced synthesis of albumin associated with impaired liver function. Previous alcoholism may have contributed.

Finally, Gundersen ${ }^{9}$ showed that in healthy diabetics intravenous insulin may directly cause a reduction in the plasma albumin concentration. Our cases suggest that plasma osmotic pressure may be an important variable in patients treated by large volumes of crystalloid infusions and that further studies are required to elucidate mechanisms of pulmonary oedema in such patients.

ADDENDUM-Since this paper was first submitted crystalloid infusions in diabetic ketoacidosis have been the subject of some debate. ${ }^{10-13}$ The existence of the phenomenon of acute pulmonary oedema is not seriously disputed, but the mechanisms and frequency of its occurrence are controversial. We were unable to make any assertions about the likely mechanisms in our patients or what made them unusual, "at risk" patients. It would be surprising if the condition was limited to young ketoacidotic patients; in older patients heart failure or pneumonia is probably often diagnosed in error.

We thank Dr A Fisher, department of anaesthetics, and Dr R Wilkinson, department of clinical pathology, for their help.

\section{References}

1 Fleet AB. "Shock lung" syndrome following diabetic ketoacidosis; treatment with heparin. Chest $1973 ; 63: 434-6$.

${ }^{2}$ Kwaan HC, Colwell JA, Suwanwela N. Disseminated intravascular coagulation in diabetes mellitus with reference to the role of increased platelet aggregation. Diabetes $1972 ; 21: 108-13$.

3 Timperley WR, Preston FE, Ward JD. Cerebral intravascular coagulation in diabetic ketoacidosis. Lancet $1974 ; \mathrm{i}: 952-6$.

4 Powner D, Snyder JV, Grenvik A. Altered capillary permeability complicating recovery from diabetic ketoacidosis. Chest $1975 ; 68: 253-5$.

5 Sprung CL, Rackow EC, Fein IA. Pulmonary oedema: a complication of ketoacidosis. Chest 1980;77:687-8.

${ }^{6}$ Fein IA, Rackow EC, Sprung CL, Grodman R. Relation of colloid osmotic pressure to arterial hypoxemia and cerebral oedema during crystalloid volume loading of patients with diabetic ketoacidosis. Ann Intern Med $1982 ; 96: 570-5$.

${ }_{7}$ Anonymous. Plasma protein and pulmonary oedema. (Editorial.) Lancet $1980 ;$ ii : 1012 .

${ }^{8}$ Stein L, Beraud J, Morissette M, Da Luz P, Weil MH, Shubin H. Pulmonary oedema during volume infusion. Circulation 1975;52:483-8.

${ }^{9}$ Gundersen $\mathrm{HJ}$, Christensen NJ. Intravenous insulin causing loss of intravascular water and albumin and increased adrenergic nervous activity in diabetics. Diabetes $1977 ; 26: 551-7$.

10 Anonymous. Crystalloid infusions in diabetic ketoacidosis. (Editorial.) Lancet 1982 ;ii:308-9.

11 Hillman KM. Crystalloid infusions in diabetes. Lancet 1982;ii:548.

12 Axelrod L. Crystalloid infusions in diabetes. Lancet $1982 ; \mathrm{ii}: 549$.

13 Matz R, Carroll P. Crystalloid infusions in diabetes. Lancet 1982;ii :549.

(Accepted 12 fanuary 1983)

\section{SHORT REPORTS}

\section{Arthritis caused by Mycoplasma salivarium in hypogammaglobulinaemia}

Interest in the role of mycoplasmas in chronic arthritis in man is stimulated by the resemblance to rheumatoid arthritis of natural and experimentally produced chronic arthritis in animals. ${ }^{12}$ Although some workers have claimed to have isolated mycoplasmas from synovial fluid or tissue of patients with rheumatoid arthritis, the only certain isolation from joints has been almost solely in patients with antibody deficiency. The species isolated so far have been Mycoplasma pneumoniae and Ureaplasma urealyticum (ureaplasma organisms). We report on a patient with hypogammaglobulinaemia who had a chronic joint infection with $M$ salivarium, generally regarded as a commensal in the mouth.

\section{Case report}

The patient was a 39 year old woman with late onset hypogammaglobulinaemia diagnosed when she was 31 years old, at which time she had a symmetrical polyarthritis and a history of bronchiectasis. Investigations showed hypogammaglobulinaemia; radiography of the hands and knees did not show erosive changes. Bacteria and mycoplasmas were not isolated from the effusion and synovial tissue of a knee joint. Immunoglobulin replacement treatment was started, and the polyarthritis resolved after six weeks.

She remained well until she was 37 years old, when she developed intermittent diarrhoea, low grade fever, and a painful swollen right knee. Examination showed diffuse lymphadenopathy and a right knee effusion. Fluid from the affected knee contained $7 \cdot 4 \times 10^{9}$ cells $/ 1$, all of which were mononuclear. Results of routine bacteriological cultures were negative. Culture of the synovial fluid in mycoplasma media, ${ }^{3}$ however, yielded $M$ salivarium $\left(\geqslant 5 \times 10^{9}\right.$ organisms/l) after incubation for seven days at $37^{\circ} \mathrm{C}$. $M$ hominis and $U$ urealyticum were isolated from throat and vaginal swabs taken at the same time as the synovial fluid. Campylobacter organisms were isolated from stool specimens. She was treated with intravenous erythromycin $500 \mathrm{mg}$ four times daily) for the campylobacter infection: the diarrhoea stopped promptly and the arthritis diminished considerably within five days. Later $M$ salivarium was found to be sensitive to $1 \mathrm{mg}$ erythromycin/1.

She continued treatment with oral erythromycin $(500 \mathrm{mg}$ four times daily) for four weeks after discharge from hospital and remained well except for slight pain and swelling of her right knee. Further aspiration six months later provided a minimal amount of synovial fluid, culture of which again yielded
$M$ salivarium $\left(\geqslant 5 \times 10^{6}\right.$ organisms/1) after prolonged incubation. Despite oral treatment with erythromycin for a further two months the pain in her knee persisted and synovectomy was performed later. An arginine hydrolysing mycoplasma was isolated $\left(5 \times 10^{5}\right.$ organisms/l) from the synovium obtained at operation. It was almost certainly $M$ salivarium but was difficult to identify conclusively. Postoperatively her knee remained hot and slightly tender despite oral erythromycin ( $250 \mathrm{mg}$ four times daily). When minocycline (100 mg twice daily) was substituted, however, her symptoms resolved rapidly.

\section{Comment}

This is the first reported isolation of $M$ salivarium from the joint of a patient with arthritis. This arginine hydrolysing mycoplasma is a normal commensal in the mouth of dentulous people. ${ }^{4}$ Its recovery from the joint specimens does not appear to have been due to spurious contamination because isolations were made on three separate occasions months apart. The initial presentation of hypogammaglobulinaemia with polyarthritis and its resolution with treatment with gammaglobulin is well recognised. ${ }^{5}$ Mycoplasmas and bacteria were not isolated when this patient presented initially, but the earlier arthritis may possibly have been caused by the same micro-organism.

It is now clear that patients with antibody deficiency are prone to arthritis and other infections with mycoplasmas and ureaplasmas, implying that humoral mechanisms have an important role in host defences against these organisms. The $M$ salivarium in this patient's joint probably originated in the mouth and gained access to the circulation owing to lack of specific antibody.

Mycoplasmal infection must be borne in mind when patients with hypogammaglobulinaemia present with arthritis. The correct diagnosis depends on early aspiration of the affected joint, the fluid obtained being cultured specifically for mycoplasmas. This may have to be undertaken by laboratories used to handling and identifying these micro-organisms, as culture may have to be prolonged for them to be isolated. Tests of sensitivity to antibiotics should be undertaken to guide treatment. In retrospect, our experience suggests that treatment should begin early with intravenous tetracycline, to which most mycoplasmas are sensitive, and may have to be continued for some months.

1 Taylor-Robinson D, Taylor G. Do mycoplasmas cause rheumatic disease ? In: Dumonde DC, ed. Infection and immunology in the rheumatic diseases. London: Blackwell, 1976:177-86. 